\title{
A study on work engagement among nurses in Japan: the relationship to job-demands, job-resources, and nursing competence
}

\author{
Toshihiro Hontake ${ }^{* 1}$, Hiromi Ariyoshi ${ }^{2}$ \\ ${ }^{1}$ Saga University Graduate School of Medical Science, Saga city, Japan \\ ${ }^{2}$ Saga University, Saga city, Japan
}

Received: December 9, 2015

Accepted: January 13, 2016

Online Published: January 19, 2016

DOI: $10.5430 /$ jnep.v6n5p111

URL: http://dx.doi.org/10.5430/jnep.v6n5p111

\begin{abstract}
Objective: This study reviewed the state of work engagement among nurses in Japan, and the relationship to job demands and job resources. Additionally, our research attempted to clarify the role of work engagement on the effects that job-resources have on nursing competence.

Methods: A questionnaire composed of the Utrecht Work-Engagement Scale the Brief Scales for Job Stress-Nurse and the Clinical Nursing Competence Self-Assessment Scale was distributed to 917 nurses working in hospitals in Japan.

Results: A negative correlation, although slight, was found between job-demands and work engagement. There was a positive correlation between job-resources and work engagement, however, work engagement was only found to be significantly affected by job fulfillment. Work engagement seems to mediate the relationship between job-resources and job-demands however the results from the path analysis did not fully support this model.

Conclusions: Our study did not sufficiently explain the relationships between variables. It can be suggested that the correlations between job-resources, job-demands, and work engagement are bidirectional or circulatory, rather than unidirectional.
\end{abstract}

Key Words: Work engagement, Job-demands, Job-resources, Nursing competence

\section{INTRODUCTION}

Several studies have been conducted in Japan concerning burn-out syndrome among hospital nurses, and the correlations between mental health and work-related stress. ${ }^{[1,2]}$ Regardless, the job separation rate for nurses working in Japanese hospitals remains over $10 \% .{ }^{[3-5]}$ Our theory is that hospital administrators, although aware of the declining mental state of nurses, experience intervention difficulty and require tools to help nurses sustain a positive daily work environment.

\subsection{Work engagement}

Work engagement is defined as a positive affective motivational state of fulfillment, manifested as vigor, dedication, and absorption. ${ }^{[6]}$ Vigor is defined as high levels of energy and mental resilience at work. Dedication is described as strong involvement in one's work accompanied by feelings of enthusiasm and significance. Absorption relates to beJapan.

*Correspondence: Toshihiro Hontake; Email: hontake0525@me.com; Address: Saga University Graduate School of Medical Science, Saga city, 
ing fully engrossed in one's work and having difficulties detaching oneself from it. ${ }^{[7]}$

\subsection{Factors related to work engagement and their out- comes}

The relation between work engagement and job-resources and personal resources was clarified. ${ }^{[7-14]}$ In addition, it has also been shown that work engagement alleviates jobdemands. Higher levels of work engagement lead to positive work outcomes. ${ }^{[11,14-18]}$ Research conducted on nurses in foreign countries have shown that high levels of work engagement lead to contributions to causes outside of nursing, higher quality of care for nursing patients, and motivation to voice opinions in conferences. ${ }^{[19,20]}$ Research conducted in Japan concerning work engagement in nurses has shown the relation towards age, marital status, years of experience, employment/work status, desire to separate from job, role in the workplace, and support from superiors. ${ }^{[21-24]}$ However, previous studies conducted in Japan have not shown the relation between work engagement and job demands and outcomes, or the role of work engagement in the relationship between job-resources and outcomes.

\subsection{Hypothesis}

For these reasons, the authors have examined the following hypothesis.

Hypothesis 1: There is a negative relationship between work engagement and job-demands (quantitative and qualitative burdens, interpersonal relationship difficulties at work, critical degree of the patient, patient-nurse relationship).

Hypothesis 2: Job-resources (level of discretion, support from colleagues and superiors, job fulfillment) and level of education, job rank, and nursing qualifications all had a positive relation to work engagement.

Hypothesis 3: Work engagement mediates the effect and increases the level of influence of job-resources on nursing competence.

\section{METHOD}

\subsection{Participants and procedures}

The subjects of our survey were nurses who have worked continuously for over a year in hospitals in Japan. The authors, who received consent from the subject hospitals, distributed the survey to 917 nurses, and retrieved the anonymous surveys at collection stations using the placement method. 837 surveys were collected ( $90.9 \%$ collection rate), and 613 surveys were considered valid ( $73.2 \%$ valid survey rate).

112

\subsection{Measure}

Basic attributes for analysis were gender, age, marital status (single, married, divorced), and years of nursing experience. Attributes for analyzing job-resources were level of education, rank, and possession of higher level qualifications for nursing (public health nurse, midwife, or Japanese Nursing Association accredited Certified Nurse: CN, Certified Nurse Specialist: CNS, or Certified Nurse Administrator: CNA).

Work engagement: Work engagement was measured using 9 items from Japanese version of the Utrecht Work Engagement Scale (UWES-J). ${ }^{[25]}$ UWES-J is composed of 3 sub-concepts of "vigor", "dedication", and "absorption".

Job-demands/Job-resources: Job-resources and jobdemands were measured using the Brief Scales for Job StressNurse (BSJS-NS). ${ }^{[1]}$ Job-demands were measured using the sub-scales of "quantitative burden of work" (workload, availability of free time), "qualitative burden of work" (deadlock at work, complicated or difficult work content), "interpersonal relationship difficulties at work" (interpersonal difficulties among the work team), "the critical degree of the patient" (life or death illnesses) and the "patient-nurse relationship" (harassing or threatening behaviors by patients towards nurses). Job-resources were measured using the subscales of "discretion" (task progression, ability to vocalize opinions), "support from colleagues and superiors" (support in the workplace from colleagues and superiors), and "fulfillment" (work satisfaction, ability to display competency).

Nursing Competence: Nursing competence was measured using the Clinical Nursing Competence Self-Assessment Scale (CNCSS). ${ }^{[26]}$ This scale is composed of the four concepts of "basic nursing competence", "development capability according to level of health", "coordinative capability between care environment and team structure", and "ability to devote oneself to nursing competency". For this study, chose "basic nursing competence" and "ability to devote oneself to nursing competency" as our dependent variables taking into consideration that our subjects were nurses who worked in various hospital departments.

\subsection{Analysis}

For Hypothesis 1 and 2, Pearson's correlation coefficient and multiple regression analysis were used to evaluate the items pertaining to BSJS-Ns and UWES. Comparison beyond group 3 was clarified through one-way analysis of variance and Tukey's test. Hypothesis 3 was made clear by using path analysis to evaluate the role of UWES in BSJS-Ns and CNCSS. We used SPSS ver. 22 and SPSS AMOS ver. 23 as our analysis software. 


\subsection{Ethical considerations}

Approval was obtained for this study from Saga University Medical School Research Ethical Committee and the ethical committees of the hospitals who granted permission for our surveys.

\section{RESULTS}

The Cronbach $\alpha$ coefficient for each scale was UWES.928, BSJS-Ns.776, and CNCSS.937. The background information for the subjects can be seen in Table 1 .

Table 1. Base line characteristics

\begin{tabular}{lll}
\hline Characteristics & Percent (\%) \\
\hline Gender n (\%) & 447 & 72.9 \\
$\quad$ Female & 37.5 & 10.2 \\
Mean age yr (SD) & 14.4 & 9.7 \\
Nursing experience Mean yr (SD) & 8.0 & 6.9 \\
Length of service & & \\
Marital status n (\%) & 337 & 55.0 \\
Married & 229 & 37.3 \\
Single & 47 & 7.7 \\
$\quad$ Divorced & & \\
Education n (\%) & 557 & 85.8 \\
$\quad$ Bachelor & 56 & 14.2 \\
$\geq$ Bachelor & & \\
Rank n (\%) & 488 & 79.6 \\
Staff & 125 & 20.4 \\
Administor & 81 & 22.9 \\
Possession of higher level qualifications for nursing n (\%) \\
Only a nurse license & 534 & 87.1 \\
Higher level qualitification & & \\
\hline
\end{tabular}

\subsection{Comparison of the degree of work engagement by basic attributes}

Table 2 shows the results of the comparison between the sub-scale scores for work engagement and basic attributes. Marital status, motive for job placement, rank, and status of employment all showed significant differences against independent item scores for work engagement.

\subsection{The relationship between work engagement and job- demands and job-resources}

Table 3 shows the correlation between job-demands and jobresources, and the sub-scale scores for work engagement. Table 4 shows the results of the multiple regression analysis conducted with sub-scale scores of work engagement as the dependent variables, and job-demands and job-resources as the independent variables. There was a strong correlation between "fulfillment" and work engagement. "Fulfillment" and "critical degree of the patient" showed a significant relation to sub-scale items for work engagement.

\subsection{The role of work engagement in the relation between job-resources and nursing competence}

Figure 1 shows the mediatory effect of work engagement on the relation between job-resources and nursing competence. Significant results for path analysis showed passes from "fulfillment" to "dedication", then ultimately passing through "basic nursing competence (standardized indirect effect = .222)" and "ability to devote oneself to nursing competency (standardized indirect effect $=.292)$ ".

\section{Discussion}

\subsection{The relation between work engagement and job- demands}

We could not satisfactorily explain the hypothesis 1 . Studies on nurses in foreign countries have reported that there is no relation between job-demands and work engagement. ${ }^{[19,27,28]}$ Our research showed a negative correlation, although weak, between job-demands and work engagement. The "critical degree of the patient" had a negative influence on work engagement, although there was not sufficient evidence to fully support this relation. The weak correlation between job-demands and work engagement, combined with only a partial influence of job-demands makes the results of this study similar to those of studies in foreign countries.

\subsection{The relation between work engagement and job- resources}

We could not satisfactorily explain the hypothesis 2 , because we could not explain relation of work engagement and education level, qualifications for nursing. Although job-resources showed a positive correlation with work engagement, the strongest correlation was seen with "fulfillment". Work engagement was influenced by "fulfillment". "Fulfillment" is a constructive concept of "self-effectiveness". [29] "Selfeffectiveness" is positively related to work engagenment. ${ }^{[30]}$ In short, it is possible that "fulfillment", as an element of "self-effectiveness", positively influenced work engagement. In addition, per the results of internal correlation for jobresources, there is a possibility that work engagement was indirectly positively influenced by "support from colleagues and superiors", "discretion", and "fulfillment".

Additionally, in accordance to foreign research, we also found no relation between level of education and work engagement, nor for job rank and work engagement. ${ }^{[31,32]} \mathrm{We}$ believe these results fail to show a significant difference for work engagement due to the range of educational backgrounds for nurses in Japan, and the lack of division of tasks 
by educational level.

There was no relation seen between nurses in possession of higher level qualifications for nursing and work engagement. The nurses who were licensed as public health nurses in our survey had the same ward duties as other nurses. In addition, most of CNS and $\mathrm{CN}$ had various working conditions and employment statuses, and most experienced no changes in salary, rank, or role, even after obtaining their license. ${ }^{[33,34]}$ The authors believe this setting is a factor in what may or may not significantly influence work engagement.

Table 2. Comparison of UWES(Utrecht Work Engagement Scale) by the basic attribute

\begin{tabular}{|c|c|c|c|c|c|c|c|c|c|c|c|c|c|}
\hline \multirow[b]{2}{*}{ Charastirics } & \multirow[b]{2}{*}{$\mathbf{N}$} & \multicolumn{4}{|l|}{ vigor } & \multicolumn{4}{|c|}{ dedication } & \multicolumn{4}{|c|}{ absorption } \\
\hline & & $\mathbf{M}$ & SD & $\begin{array}{l}\text { Tukey's } \\
\text { test }\end{array}$ & $p$ & $\mathbf{M}$ & SD & $\begin{array}{l}\text { Tukey's } \\
\text { test }\end{array}$ & $p$ & $\mathbf{M}$ & SD & $\begin{array}{l}\text { Tukey's } \\
\text { test }\end{array}$ & $p$ \\
\hline \multicolumn{14}{|l|}{ Gender } \\
\hline Female & 447 & 6.12 & 3.15 & & .35 & 7.89 & 3.16 & & .27 & 6.04 & 3.09 & & .30 \\
\hline Male & 166 & 6.22 & 3.49 & & & 7.64 & 3.34 & & & 5.73 & 3.29 & & \\
\hline \multicolumn{14}{|l|}{ Marital status } \\
\hline Married & 337 & 6.56 & 3.19 & \multirow{3}{*}{]$* * *$} & \multirow{3}{*}{.00} & 8.08 & 3.07 & \multirow{3}{*}{]$*$} & \multirow{3}{*}{.03} & 6.08 & 3.05 & & 15 \\
\hline Single & 229 & 5.41 & 3.15 & & & 7.39 & 3.33 & & & 5.67 & 3.18 & & .10 \\
\hline Divorced & 47 & 6.72 & 3.46 & & & 8.13 & 3.37 & & & 6.49 & 3.51 & & \\
\hline \multicolumn{14}{|c|}{ Level of education } \\
\hline$<$ Bachelor & 557 & 6.05 & 3.22 & & .68 & 7.72 & 3.21 & & .80 & 5.89 & 3.12 & & .38 \\
\hline$\geq$ Bachelor & 56 & 7.05 & 3.31 & & & 8.82 & 3.05 & & & 6.63 & 3.36 & & \\
\hline \multicolumn{14}{|l|}{ Rank } \\
\hline Staff & 488 & 5.91 & 3.31 & & .07 & 7.50 & 3.29 & & .00 & 5.66 & 3.16 & & .02 \\
\hline Administer & 125 & 7.06 & 2.80 & & & 9.09 & 2.51 & & & 7.14 & 2.81 & & \\
\hline \multicolumn{14}{|c|}{ Possession of higher level qualifications for nursing } \\
\hline $\begin{array}{l}\text { Only a nurse } \\
\text { license }\end{array}$ & 532 & 5.97 & 3.24 & & 5 & 7.63 & 3.20 & & .29 & 5.80 & 3.11 & & .74 \\
\hline $\begin{array}{l}\text { Higher level } \\
\text { qualitification }\end{array}$ & 81 & 7.27 & 3.02 & & (.0. & 9.10 & 2.97 & & & 7.00 & 3.15 & & \\
\hline
\end{tabular}

Note. $\mathrm{M}=$ Mean; $\mathrm{SD}=$ Standard Deviation; $p=p$-Value; ${ }^{*} p<.05 ; * * p<.01 ; * * * p<.001$.

Table 3. Correlation of utrecht work engagement scale and brief scales for job stress-nurse (Pearson coefficient of correlation)

\begin{tabular}{|c|c|c|c|c|c|c|c|c|c|c|c|c|c|}
\hline & No & Variable & 1 & 2 & 3 & 4 & 5 & 6 & 7 & 8 & 9 & 10 & 11 \\
\hline \multirow{3}{*}{ W.E } & 1 & Vigor & 1 & & & & & & & & & & \\
\hline & 2 & Dedication & $.807 * *$ & 1 & & & & & & & & & \\
\hline & 3 & Absorption & $.712 * *$ & $.776^{* *}$ & 1 & & & & & & & & \\
\hline \multirow{5}{*}{ J.D } & 4 & $\begin{array}{l}\text { Quantitative } \\
\text { burden of work }\end{array}$ & $-.171^{* *}$ & $-.095^{*}$ & -.010 & 1 & & & & & & & \\
\hline & 5 & $\begin{array}{l}\text { Qualitative burden } \\
\text { of work }\end{array}$ & $-.168^{* *}$ & $-.160^{* *}$ & -.069 & $.670^{* *}$ & 1 & & & & & & \\
\hline & 6 & $\begin{array}{l}\text { Interpersonal } \\
\text { relationship } \\
\text { difficulties at work }\end{array}$ & $-.231^{* *}$ & $-.204 * *$ & $-.138 * *$ & $.281^{* *}$ & $.304 * *$ & 1 & & & & & \\
\hline & 7 & $\begin{array}{l}\text { Critical degree of } \\
\text { the patient }\end{array}$ & $-.181^{* *}$ & -.072 & -.075 & $.324^{* *}$ & $.243^{* *}$ & $.193^{* *}$ & 1 & & & & \\
\hline & 8 & $\begin{array}{l}\text { Patient-nurse } \\
\text { relationship }\end{array}$ & $-.189 * *$ & $-.207^{* *}$ & $-.157 * *$ & $.164^{* *}$ & $.236 * *$ & $.157 * *$ & $.188^{* *}$ & 1 & & & \\
\hline \multirow{3}{*}{ J.R } & 9 & Discretion & $.231 * *$ & $.236 * *$ & $.161^{* *}$ & -.059 & $-.163 * *$ & $-.156 * *$ & .050 & $-.085^{*}$ & 1 & & \\
\hline & 10 & $\begin{array}{l}\text { Support from } \\
\text { colleagues and } \\
\text { superiors }\end{array}$ & $.243^{* *}$ & $.244^{* *}$ & $.177 * *$ & $-.085 *$ & $-.100 *$ & $-.327 * *$ & $.085 *$ & -.027 & $.308^{* *}$ & 1 & \\
\hline & 11 & Fulfillment & $.529 * *$ & $.651^{* *}$ & $.523 * *$ & -.022 & $-.150 * *$ & $-.171^{* *}$ & $.100 *$ & $-.182 * *$ & $.369 * *$ & $.398 * *$ & 1 \\
\hline
\end{tabular}

Note. W.E = Work-engagement; J.D = Job demands; J.R = Job resources; $p$-Value; ${ }^{*} p<.05 ; * * p<.01$. 
Table 4. The relation between utrecht work engagement and BSJS-Ns (multiple regression analysis)

\begin{tabular}{|c|c|c|c|c|c|c|c|c|c|c|c|}
\hline \multirow{2}{*}{ Variable } & \multicolumn{3}{|c|}{ Vigor } & & \multicolumn{4}{|c|}{ Dedication } & \multicolumn{3}{|c|}{ Absorption } \\
\hline & B & SE & $\boldsymbol{\beta}$ & & B & SE & $\beta$ & & B & SE & $\beta$ \\
\hline Fulfillment & 0.86 & 0.05 & $0.53 * * *$ & Fulfillment & 1.04 & 0.05 & $0.65 * * *$ & Fulfillment & 0.84 & 0.05 & $0.54 * * *$ \\
\hline $\begin{array}{l}\text { Critical degree } \\
\text { of the patient }\end{array}$ & -0.29 & 0.05 & $-0.20 * * *$ & $\begin{array}{l}\text { Critical degree } \\
\text { of the patient }\end{array}$ & -0.18 & 0.05 & $-0.12 * * *$ & $\begin{array}{l}\text { Critical } \\
\text { degree of } \\
\text { the patient }\end{array}$ & -0.18 & 0.05 & $-0.13 * * *$ \\
\hline $\begin{array}{l}\text { Interpersonal } \\
\text { relationship } \\
\text { difficulties at } \\
\text { work }\end{array}$ & -0.13 & 0.06 & $-0.08 *$ & $\begin{array}{l}\text { Interpersonal } \\
\text { relationship } \\
\text { difficulties at work }\end{array}$ & -0.11 & 0.05 & $-0.07 *$ & & & & \\
\hline $\begin{array}{l}\text { Quantitative } \\
\text { burden of work }\end{array}$ & -0.10 & 0.05 & $-0.07 *$ & & & & & & & & \\
\hline$R^{2}$ & 0.35 & & & & 0.45 & & & & 0.29 & & \\
\hline
\end{tabular}

4.3 The mediatory role of work engagement in the relation between job-resources and nursing competency

This study clarified the influence of "fulfillment" (via "enthusiasm") on nursing competency, although we could not satisfactorily explain the hypothesis 3 , because the value of $R^{2}$ was low. The reason for the results achieved was due to the unidirectional frame of our research which used the Job-Demands-Resource Model (JD-R model) to consider jobresources' effect on work engagement and nursing compe- tency. Baker (2011) developed the JD-R Model, and proved the existence of the positive gain spiral as a circulating relationship with positive effects between work engagement and job-resources. ${ }^{[35]}$ Positive gain spiral showed results even when the subjects were nurses. The positive gain spiral suggested in this study can be seen in Figure 2. In order to clarify the existence of the results in Figure 2, we must conduct further research based on the positive gain spiral model.

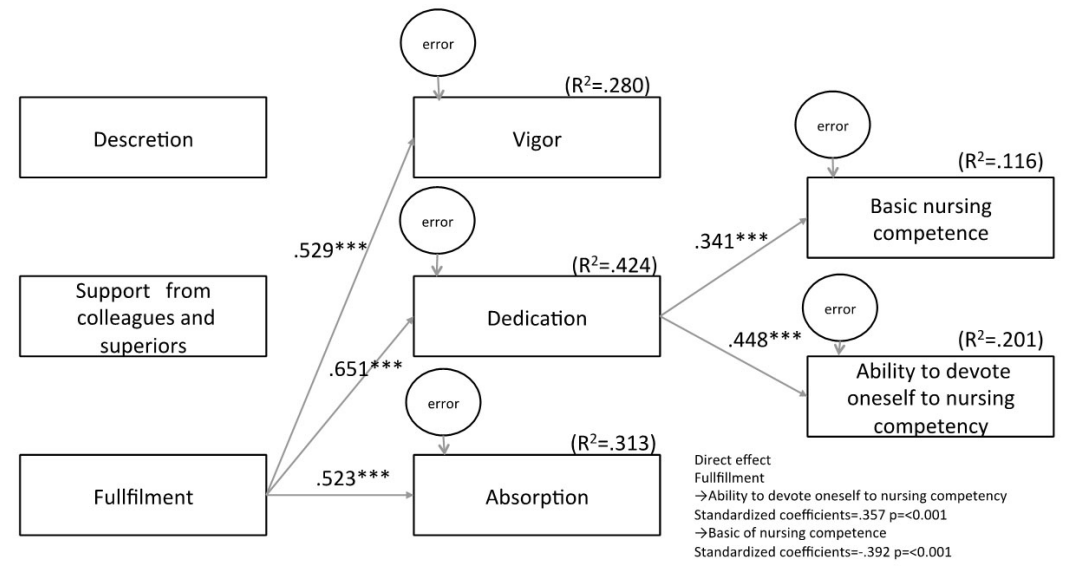

Figure 1. The wealth of the work and the arbitration role of work engagement in the nursing practice ability $* * * p<.001$

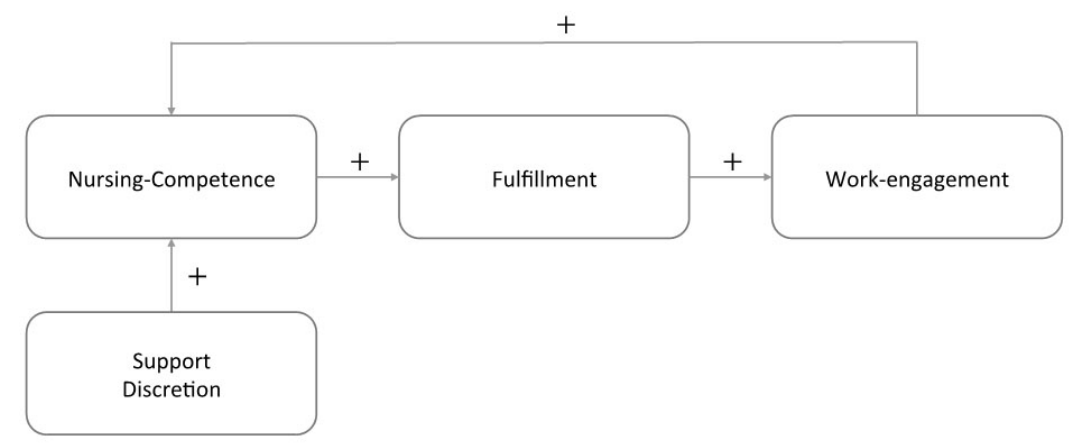

Figure 2. Nursing competence, fulfillment, work-engagement postive gain spiral 


\section{Conclusion}

Our research was not able to sufficiently clarify the relationship between job-demands, job-resources and work engagement, nor to explain whether work engagement played a role in the effect of job-resources and nursing competency. The weakness of this study was in the inability to clarify the positive gain spiral in the relationship between job-resources, work engagement, and nursing competency. For future re- search, there is a need to organize variables and framework outlines, and to clarify the existence of the positive gain spiral among nurses. In addition, we hope to explore other necessary variables and supportive factors which may positively affect this spiral.

\section{CONFlicts OF InTEREST Disclosure}

The authors declare that there is no conflict of interest.

\section{REFERENCES}

[1] Kageyama T, Nishikido N, Kobayashi T, et al. Characteristics of Work Stress among Hospital Nurses and its Association with Mental Health. The Japan Journal of Mental Health. 2001; 16(1): 69-81.

[2] Inaoka F, Kawano M, Munakata T. Nurses' Burnout and Their Social, Behavioral Patterns. Journal of Japan Academy of Nursing Science. 1986; 6(3): 50-60. http://dx.doi.org/10.5630/jans1981.6. 3_50

[3] Japanese Nursing Association. News release 2015 March 31. 2015 Oct. Available from: http://www.nurse.or.jp/up_pdf/20150 331145508_f.pdf

[4] Japanese Nursing Association. News release 2013 March 7. 2015 Oct. Available from: http://www.nurse.or.jp/up_pdf/20130 307163239_f.pdf

[5] Japanese Nursing Association. News release 2011 April 21. 2015 Oct. Available from: http://www.nurse.or.jp/home/opinion /newsrelease/2011pdf/20110420.pdf

[6] Schaufeli WB, Salanova M, Gonzalez-Roma B, et al. The measurement of engagement and burnout: A two sample confirmative analytic approach. J Happiness Stud. 2002; 3(1): 71-92. http: //dx.doi.org/10.1023/A:1015630930326

[7] Schaufeli WB, Bakker AB. Job demands, job resources, and their relationship with burnout and engagement: A multi-sample study. Journal of Organizational Behavior. 2004; 25(3): 293-315. http: //dx.doi.org/10.1002/job. 248

[8] Bakker A B, Demerouti E, Verbeke W. Using The Job DemandsResources Model To Predict Burnout And Performance. Human Resource Management. 2004; 43(1): 83-104. http://dx.doi.org $/ 10.1002 / \mathrm{hrm} .20004$

[9] Schaufeli WB, Bakker AB, Willem VR. How changes in Job demands and resources predict burnout, work engagement, and sickness absenteeism. Journal of Organizational Behavior. 2009; 30(7): 893-917. http://dx.doi.org/10.1002/job.595

[10] Hakanen JJ, Bakker AB, Demerouti E. How dentists cope with their job demands and stay engaged: The moderating role of job resources. European Journal of Oral Science. 2005; 113(6): 479487. PMid:16324137 http://dx.doi.org/10.1111/j.1600-0 722.2005.00250.x

[11] Hakanen JJ, Bakker AB, Schaufeli WB. Burnout and work engagement among teachers. Journal of School Psychology. 2006; 43(6): 495-513. http://dx.doi.org/10.1016/j.jsp.2005.11.001

[12] Bakker AB, Hakanen JJ, Demerouti E, et al. Job resources boost work engagement, particularly when job demands are high. Journal of Educational Psychology. 2007; 99(2): 274-284. http://dx.doi .org/10.1037/0022-0663.99.2.274

[13] Xanthopoulou D, Bakker AB, Demerouti E, et al. The role of personal resources in the job demands-resources model. Interna- tional Journal of Stress Management. 2007; 14(2): 121-141. http: //dx.doi.org/10.1037/1072-5245.14.2.121

[14] Xanthopoulou D, Bakker AB, Demerouti E, et al. Work engagement and financial returns: A diary study on the role of job and personal resources. Journal of Occupational and Organizational Psychology. 2009; 82(1): 183-200. http://dx.doi.org/10.1348/0963179 $08 \times 285633$

[15] Salanova M, Schaufeli WB. A cross-national study of work engagement as a mediator between job resources and proactive behavior. The International Journal of Human Resource Management. 2008; 19(1): 116-131. http://dx.doi.org/10.1080/09585190701763982

[16] Xanthopoulou D, Bakker AB, Heuven E, et al. Working in the sky: a diary study on work engagement among flight attendants. Journal of Occupational Health Psychology. 2008; 13(4): 345-356. PMid:18837629 http://dx.doi.org/10.1037/1076-8998.13 .4 .345

[17] Hakanen JJ, Perhoniemi R, Salla TT. Positive gain spirals at work: From job resources to work engagement, personal initiative and workunit innovativeness. Journal of Vocational Behavior. 2008; 73(1): 78-91. http://dx.doi.org/10.1016/j.jvb.2008.01.003

[18] Bakker AB, Bal MP. Weekly work engagement and performance: A study among starting teachers. Journal of Occupational and Organizational Psychology. 2010; 83(1): 189-206. http://dx.doi.org /10.1348/096317909X402596

[19] Abdelhadi N, Drach ZA. Promoting patient care: Work engagement as a mediator between ward service climate and patientcentred care. Journal of Advanced Nursing. 2012; 68(6): 12761287. PMid:21913960 http://dx.doi.org/10.1111/j.1365-2 $648.2011 .05834 . \mathrm{x}$

[20] Salanova M, Lorente LC, Maria J, et al. Linking transformational leadership to nurses' extra-role performance: The mediating role of self-efficacy and work engagement. Journal of Advanced Nursing. 2011; 67(10): 2256-2266. PMid:21535088 http://dx.doi .org/1 $0.1111 / \mathrm{j} .1365-2648.2011 .05652 . \mathrm{x}$

[21] Matsumoto Y, Toyomasu K, Mihashi M, et al. Study on the factors affecting on the work engagement of the nurses working at University Hospital: by use of Utrecht Work Engagement Scale. The Journal of the Kurume Medical Assosiation. 2010; 73: 138-146.

[22] Kawauchi E, Ohashi K. Relationship among Work Engagement, Job satisfaction and Turnover Intention of Registered Midwives and Nurses Working in Public Hospitals Providing Secondary Medical Care. The Journal of the Japan Academy of Nursing Administration and Policies. 2011; 15(1): 39-46.

[23] Fukuoka E, Taniguchi T, Kakehashi Y. The relationship between work engagement and a desire to leave employment among nursing staff: Including work-related stress. Nursing care research. 2013; 12(3): $1-10$ 
[24] Sato Y, Miki A. Influences of Job Stress, Coping Profile and Social Support on Work Engagement among Hospital Nurses-A Comparative Analysis According to Their Years of Clinical Experience. The Journal of Science of Labour. 2014; 90(1): 14-25.

[25] Shimazu A, Shaufeli WB. Work engagement in Japan: Validation of the Japanese Version of Utrecht Work Engagement Scale. Applied Psychology. 2008; 57(3): 510-523. http://dx.doi.org/10.11 $11 / j .1464-0597.2008 .00333 . x$

[26] Kudo M, Nakayama Y, Ishihara M, et al. A Comparison of Construct in Two Questionnaires for Measuring Clinical Nursing Competence. Bulletin of Fukushima School of Nursing. 2012; 14: 13-22.

[27] Bacon CT, Mark B. Organizational effects on patient satisfaction in hospital medical-surgical units. The Journal of Nursing Administration. 2009; 39(5): 220-227. PMid:19423987 http://dx. doi .org /10.1097/NNA. 0b013e3181a23d3f

[28] Barbara A, Linda CH, Michael B, et al. Does safety climate moderate of staffing adequacy and work conditions on nurse injuries? Journal of Safety Research. 2007; 38(4): 431-446. PMid:17884430 http://dx.doi.org/10.1016/j.jsr.2007.04.004

[29] Bandura A. Self-efficacy: Toward a unifying theory Behavioral change. Psychological Review. 1977; 84(2): 191-215. http://dx .doi.org/10.1037/0033-295X.84.2.191

[30] Xanthopoulou D, Bakker AB, Demerouti E, et al. The role of personal resources in the job demands-resources model. Interna- tional Journal of Stress Management. 2007; 14(2): 121-141. http: //dx.doi.org/10.1037/1072-5245.14.2.121

[31] Sasaki J, Nanba M, Ninomiya K. Work engagement and its relevant factors among home visit nursing administers. Bulletin of Faculty of Health and Welfare Science Okayama Prefectural University. 2014; 21(1): 35-43.

[32] Jenaro C, Noelia FN, Orgaz MB, et al. Vigor and dedication in nursing professionals: towards a better understanding of work engagement. Journal of Advanced Nursing. 2011; 67(4): 865875. PMid:21129008 http://dx.doi.org/10.1111/j.1365-2 $648.2010 .05526 . x$

[33] Japanese Nursing Association. Situation of Certified Nurse Specialist new Certified person 2007. 2015 Aug. Available from: http://nintei.nurse.or.jp/nursing/wp-content/u ploads/2012/11/CNS-katudouzyoukyou2007.pdf

[34] Japanese Nursing Association. Report on the activities and achievements of the certified nurse 2012. 2015 Aug. Available from: http://nintei.nurse.or.jp/nursing/wp-content/u ploads/2015/04/cn-2012chosa20150403.pdf

[35] Llorens S, Schaufeli WB, Bakker AB, et al. Does a positive gain spiral of resources, efficacy beliefs and engagement exist? Computers in Human Behavior. 2007; 23(1): 825-841. http://dx.doi.org $/ 10.1016 / \mathrm{j} . \mathrm{chb} .2004 .11 .012$ 